\title{
Investigating the Effectiveness of Applying Mobile Advergames in Tourism Marketing - An Exploratory Study about Egypt
}

\author{
Mrs/ Yasmine Elsayeh* \\ Ass. Lecturer, Faculty of Tourism andHotel Management, Pharos University, Egypt \\ *Corresponding Author: Mrs/ Yasmine Elsayeh, Ass. Lecturer, Faculty of Tourism andHotel \\ Management, Pharos University, Egypt
}

\begin{abstract}
Traditional marketing communication techniques are of diminishing effectiveness and marketers have developed creative applications to attract consumers. The contemporary multiplatform environment, connecting many different devices, became a privileged ambient for advertising and marketing campaigns. In this context, it is also possible to cast a message for a brand, product or service using a ludic language through a gaming format (Silverstone, 2007), Therefore, Mobile Advergames can be seen as an attractive and new marketing tool that increases product, brand and company awareness. The purpose of this study is to provide an understanding of the qualities and potentials of the Mobile advergames as an advertising and marketing tool for the tourism industry in Egypt. Firstly, an overview about advergames is provided, as well as a review of existing literature regarding its effectiveness. The study next examines the mobile Advergames practices in the tourism industry. The results showed that the games were successful in branding, tourism marketing and city integration in a game.
\end{abstract}

Keywords: Mobile Advergames, Tourism marketing, Tourist perception, Destination image, Egypt

\section{INTRODUCTION}

The image of tourist destinations is the product of all the experiences of an individual. It may be influenced by a series of information sources. All available instruments and tools should be utilized in the present super competitive environment for the maintaining the image of the destination one of these instruments "Mobile Advergames", Mobile advergames can be faced as an effective tool to change the image of destinations and generate visit intentions (Mráek, 2012).

Since the 1970s and 80s, video games have been increasing their popularity over time as a form of entertainment. Firstly oriented towards a male audience, the video game industry has made big efforts to expand its market and reach more kinds of people, especially women and families. (Domínguez, 2013).New technologies such as social media, mobile technology, and gaming provide technological tools for developing such experiences. Indeed, the travel industry has always been one of the first ones to engage new initiatives. According to the World Travel Market Report gamification and Mobil Advergames are major trends for the coming years in tourism. (Domínguez, 2013 ; Xu, 2012).Advergames can be a powerful tool to buildbrand loyalty and collect crucial data about existingand potential customers. Advergames are seen as conceptually new and an innovative channel of communication especiallyto reach well-defined target markets.(C, eltek, 2010)

The current use of gaming by the tourism industry can be divided into two types: online/offlinegames mainly used for brand awareness, to attract potential customers and to build up a destination image, location based mobile games mainly used to encourage more engagement on site and to enhance tourists on site experiences with the destination in a more fun and informative way.(Xu, 2012 ; Bughin, 2011).However, these game apps are not always successful. Some fail to engage travelers, as they lack of fun and hardly implement facts about tourist spots. Game developers who have a technical background are often not fully aware of tourists' needs and motivation to play. Therefore, a user centered approach in game design is critical. A sufficient understanding of tourist players' motives and gaming experiences will be helpful in designing these games. (Xu, 2012)This study is intended to investigate the use of mobile advergames to improve destination image. 


\section{LITERATURE REVIEW}

\subsection{Tourist Destination Image Formation}

Destination image has been one of the key areas of tourism research for more than four decades (Svetlana \&Juline, 2010). Image is defined as "The people feelings of anything that they aware" (Boulding, 1956). Destination image is defined as "An expression of knowledge, impressions, prejudices, imaginations and emotional thoughts an individual has of a specific place" (Lawson \&Bovy, 1977). Destination image also defined as "the overall perception of the destination that is formed by processing information from various sources over time" (Assael, 1984).Or "Ideas or perceptions held individually or collectively about a destination by people" (Embacher\&Buttle, 1989). Another definition "Is an interactive system of thoughts, opinions, feelings, visualizations, and intentions toward a destination" (Tasci et al., 2007).

Destination image made up of two components of image, the components were organic images and induced images. Organic images formed by individuals themselves through past experiences with destinations and unbiased sources of information (news, reports, newspaper articles and movies). Induced images created through information received from external sources, including destination advertising and promotion (Gunn, 1972).

\subsection{Advergaming}

Many companies have begun to use the internet as part of their marketing mix; the newest and 'hottest' mass media marketing strategy is advergaming, the emergent international industry of online games created solely to promote brands (Kretchmer, 2003). The term 'advergame' refers to games created by companies to promote their products or brand by combining 'advertisement', 'computer games' and 'mobile phones'. So, Advergaming is the use of interactive gaming technology to deliver embedded advertising messages to consumers. Advergames have been defined also as online games that incorporate marketing content (Gura u, 2008 ; Gurãu, 2002),Or is the use of interactive gaming technology to deliver embedded advertising messages to consumers. Advergaming incorporates branding directly into the gaming environment.(Winkler, 2006 ; Ayada, 2012 ; Marius, 2013).

Advergaming (advertising game) is a game established on theattributes of the brand. The game should aim atthe target, which the brand manager wants tohand-over to the public. The brand is then becomingthe hero of the game; however, thecustomer should entertain himself/herself atthe same time. After the finishing of the game,the player should learn something about thebrand/product (Pavel, 2013; Mucha, 2013 ; Wynn-Brown, 2007).

The use of games offers a variety of benefits for tourism marketing, can increase brand awareness and attract potential customers. Game design can be based on real environments, for example, tourist attractions. Therefore, it provides potential visitors an informing and entertaining setting. Games are usually presented with a virtual reality or Augmented Reality 3D technology providing an immersive and engaging experience with the virtual and real destination. Gaming provides a good opportunity to create and play in online communities as a sense of community-playing is often identified in gameplay (Xu, 2012 ; Baggio, 2014).The interest in advergames has substantially increased in the last 5 years, because of their perceived advantages which are:(Gura u, 2008)low-cost marketing in comparison with the traditional advertising channels, such as TV and radio.A captured audience that can transmit valuable personal informationabout their demographic profile, behavior, needs, attitudes and preferences. Customer retention the average time spent in an advergame is 7 to 30 minutes, which cannot be achieved in the case of a classical TV advertisement; and viral marketing $81 \%$ of the players will email their friends to try a good game.The goals of advergames are to achieve higher levels of engagement, change behaviors and stimulate innovation. (Groot, 2012).

\subsection{Types of Advergames}

Chen and Ringel (2001) provided a typology based on brand integration and immersion in the game, according to which three types of advergames exist:(Theodorou, 2010 ; Gurau, 2008 ; Buckner, 2010)

Associative - Associative advergames "support brand awareness through lifestyle association". Games such as these are frequently found and essentially mean putting your product or logo into a game that a consumer would play as a background or subtle ad within the game 
Demonstrative - Demonstrative advergames are very useful in allowing a consumer to try out a product on the Internet prior to purchasing; hopefully this type of advergame will be one of the final steps leading to a customer buying a product. One example they give in their article is Nike basketball shoe, which in the game is chosen by the consumer in the beginning of the advergame. Then throughout the game the consumer will be able to see the difference performance features of the shoe. (Svahn, 2005).

Illustrative -The function of the product directlyin the game in such a way that theplayer directly cooperates with the product insome way. Illustrative advergames are a form of sponsored promotion where the advertising messages, products or services are integrated in the games and feature during the game play. Most of the time the products are central to the game play for clear reinforcement of the brand message.

Some researcher divided advergamesas follow (advergaming, 2007 ; G. De Prato, 2010).

ATL (above the line)advergames: In this form of advergames a company a company provides interactive games on its website in the hope that potential customers will be drawn to the game and spends more time on the website, or simply become more products aware. The games may or may not be related to the product.

BTL (Below the line) advergames: this form of advergames is closer to the traditional, commercial video game developed and sold to be played on computers or game consoles, but the primary difference is that the games are developed with a specific purpose in mind. For example, United States uses advergames in order to give information about army for motivating people for joining the US army.

TTL (Through the line) advergames: this form of advergames is a bit rare, it involves the use of URL hyperlinks within the game designed to induce the player to visit a webpage.

Otherresearchers agree on the classification of advergamesas follow (Tuten, 2008 ; Graaf, 2007 ; Okur, 2011).

The Revenue-Generating Advergame: The aim of some advergames is just to make consumer play long hours of the game and make them spend hours on the website. Company makes an advergame to make costumers to pay more time on website more then they usually do. That way website becomes more crowded in terms of visitors. Company's objective is making players more aware of their product or make them more familiar with the logo or slogan.

The Attention-Gathering Advergame: This time company's intention is to make consumer more curious about advergame's subject. Beside the concern of revenue company wants player to get some information about the product which needs an explanation. During the advergame consumer learns about the subject and encouraged to investigate more. There is usually a message to give in this type of advergaming. Subjects can be very different. A very important example can be given as subject like environmental issues, global warming or unhealthy foods. Although this types aim is to give information, it does not have to be about serious topics, advergame can be just commercial which gives information about the product .

The Stealth Advergame: When you play an advergame, imagine that you are driving a Formula One car, which has a lot of stickers on it. Those stickers can be advertisements of the tire, motor, F1 sponsor's logo, or some fuel. Those advertisements hidden in the game.

\subsection{Mobile Advergames}

Since mobile phones are becoming more and more popular, and are mostly equipped with the latest technologies, then brand-owner will have a new TV-like audience who would like to pass some of his time behind his mobile phone. Actually cell phones have one big advantage over all other tech gadgets, which is that we carry them wherever we go! So approaching users through their small screens will prove to be efficient.(Advergaming, 2014)

Mobile advertising is no different than traditional advertising in regards to the need for brand awareness and loyalty in addition to product and service sales. One method is to use branded 'advergames' to get your message across and to help consumers associate your brand with something 
unique and fun. Companies are developing solutions that meld mobile entertainment and games with any client's brand. Since they are usually provided free-of-charge, advergames can be a great way to reach out to your potential audience while giving them something that's fun to use, free, and worth their time. Every time theyopen and play the game, they are re-introduced to the brand, so the more unique the game, the more brand awareness received(C, eltek, 2010)Mobil Advergaming consists of one of the less intrusive varieties of advertising so that the user doesn't feel annoyed about receiving advertising messages. In fact, advergaming gains a positive attitude from the target audience (Justin, 2008), as this one is voluntarily exposed to advertising, contributing to a higher fidelity level among the customers and the brand.(Picurelli, 2013)On the other hand, mobile games designed for advergaming make the users remember better the brand involved in the promotion process. Consequently, the companies are able to achieve their goals in a more effective way than their messages are remembered by the users and affect them. Moreover, this memorization may increase virility of the content so that the users will tend to recommend them to their friends and acquaintances, and share them via social networks.(Graaf, 2007)The attention that the users of mobile devices use to pay to the games they enjoy on their terminals (Picurelli, 2013), is an important base at the time of taking advantage of the benefits that advergaming provides to the companies. (Mucha, 2013).

\begin{tabular}{|c|c|c|c|c|c|c|}
\hline & \multicolumn{6}{|c|}{ Worldwide mobile advertising spending, by objective, 2006-201I (millions) } \\
\hline & 2006 & 2007 & 2008 & 2009 & 2010 & 2011 \\
\hline $\begin{array}{l}\text { Mobile brand ad } \\
\text { spending* }\end{array}$ & $\$ 123.8$ & $\$ 277.3$ & $\$ 644.4$ & $\$ 1,120.5$ & $\$ 2,175.3$ & $\$ 3,569.2$ \\
\hline $\begin{array}{l}\text { Mobile direct response } \\
\text { ad spending } * \text { * }\end{array}$ & $\$ 1,424.0$ & $\$ 2,495.8$ & $\$ 4,312.9$ & $\$ 6,349.8$ & $\$ 9,273.6$ & $\$ 12,654.3$ \\
\hline $\begin{array}{l}\text { Total mobile ad } \\
\text { spending }\end{array}$ & $\$ 1,547.8$ & $\$ 2,773.1$ & $\$ 4,957.3$ & $\$ 7,470.3$ & $\$ 11,448.9$ & $\$ 16,223.5$ \\
\hline
\end{tabular}

Figure (1)

Source: $h$ ttp://searchenginewatch.com/

\subsection{Advantages of Mobile Advergame}

Non-annoying advertising introduced within the content which customers are enjoying.It allows us to understand the preferences of the clients, which may at the same time, create a greater implication with the message and identification with the brand name. Advergames are a form of viral marketing in which "word of mouse" rewards customers when they help with some of the heavy lifting that comes with releasing a new product or promoting an existing brand( $C_{s}$ eltek, 2010)Databases created from the advergame can be used for demographics research.Targeted markets can be reached by your advertising (when the game link is emailed).Visitors may spend more time on your site. (Ayada,2013). Easy and smart social share integration in our games will increase the reach for your brand.Undivided AttentionMobile games are being played during lunch breaks, waiting on the bus, everywhere and any time someone feels like it. Gamers concentrate on a game and give it their undivided attention which is in turn undivided, uninterrupted attention for your brand or idea.Bring your fans to the right placehaving a game on your website additionally to having it available on mobile, is not only fun but it potentially drives much more traffic and potential fans and clients to a place where you want them to be. Be it ultimately to educate or to offer them specific products to buy or download.(advergame, 2013).

\subsection{Weaknesses of Mobile Advergame (Perez, 2009)}

The popularity of advergames and games in general will see more companies and advertisers using this form in the coming years, which could potentially lead to over saturation.Advergames still need to be fun and well designed, many advergames focus too much on the advertisement rather than the game.Hiring a videogame developer or advergaming agency is almost a necessity to tackle this issue. Availability of game development skill-set and lack of financial resources for the game companies and advertiser companies.Advergames could be expensive for playing because games neededpurchases and expensive technology devices.Most of the games had not Multilanguage application.( $\mathrm{C}_{3}$ eltek, 2010).There are less mobile advergame examples and applications in tourism 
industry and existing examples are not city, destination and country targeted advergames. And most of the tourism advergames are targeted the young customers.

\subsection{The AIDA Model in Mobile Advergames Context}

The AIDA Model (Strong, 1925) is in fact an acronym for attention, interest, desire andaction and describes a cognitive journey of a consumer that travels through four main stages. Thismodel can be approached as a tool to encourage action by stimulating the purchase of a certainproduct or service. It is a good way for advertisers to create efficient promotional campaigns. (D.Pop, 2013;Ghirvu, 2013)

Attract the attention: The advertiser has to promote the product in such way so thecustomer becomes aware of the existence of that particular service Mobile, Advergames are a type of persuasive videogames, help in attracting and retain the players'attention and make them become aware of a specific brand, in a way that traditional media is unable to do. The use of Mobile advergames can be approach for attract the public's attention over anew product. Measuring the impact of this can indicate the grade of acceptance from consumers of new products or services before they are actually available on the market.

Raise interest: Consumer interest appears when he actively expresses it in connection to a product or service that he knows about. Mobile Advergames can produce interest by including special advertising insertions that allow the players to interact with the brand and learn about special features and characteristics of a product. In aMobile advergames, the message is blend within the game action, so the player understands the use and the particular elements of the advertised product by simply following the game rules or interacting with the product during a game session.

Create desire: Desire is considered the actual aspiration to a particular product, service or brand. Marketers can take use of Mobile advergames for inducing desire for a certain product. To do this efficiently, they have to carefully choose those characteristics that are the most relevant for the product and could be adapted for the video game.

Lead to action: Action represents the final step of the buying process. Video games in particular create an environment where the player is in an active state ofmind where he could be easily influenced into getting from desire to action. When dealing with Mobile advergames, marketers can use different ways to motivate a consumer totake action and purchase the product. The most popular methods are the use of promotions, pricediscounts or vouchers which will invite the consumer to buy. This implies also different benefits forthose consumers who played the Mobile advergame when they will actually buy the product or the serviceadvertised into the game.

\subsection{Mobile Technology in Egypt}

The mobile market is one of the fastest-growing media segments in Egypt, the use of laptops and smartphones is widespread. In particular, smartphone adoption is rapidly increasing, nearing the levels of PCs and laptops, Egypt has surpassed more than 40 percent of users accessing the Internet every day on a smartphone. The smartphone is increasingly being adopted as a tether to home for travelers on the go for the focus markets, connecting them with friends and family and keeping them constantly in touch while on holiday. To a limited, but growing, extent, the smartphone is also an enabler, serving as an on-the-fly planning and booking device at their destination. Generally speaking, the tablet's place is 'on-resort', with respondents increasingly favoring the device as an entertainment center first and foremost, used most frequently to read books, read travel reviews/guides and play games(Booth, 2014).

Already, consumers are more likely to play games and access social networks on a mobile device. For other media activities, such as accessing news or browsing websites, levels of usage on smartphones are also fast approaching those on laptops or desktop computers. At the same time, marketers should consider integrating mobile into their advertising campaigns to enhance effectiveness, reach, and engagement(Baron-Cohen, 2010). According to study was carried out in 2014; it aims at evaluating the usage of technology in Middle East, the study showed the following. 


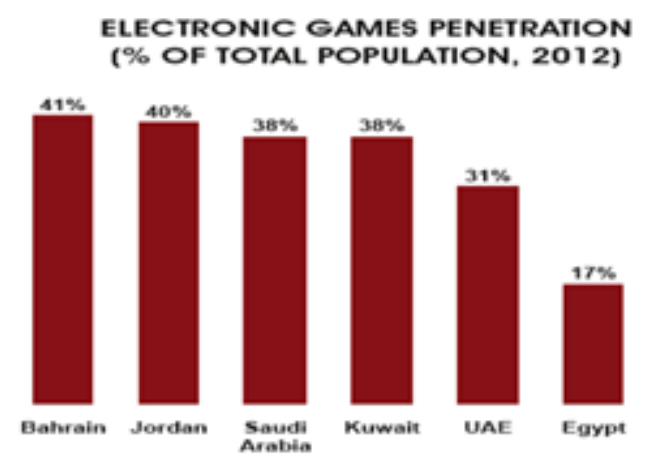

ELECTRONIC GAMES PENETRATION

TOTAL POPULATION, 2012

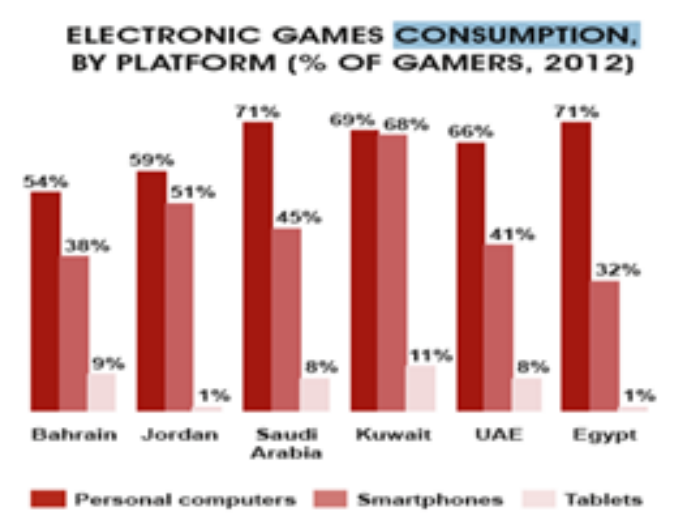

Figure (2)

Source: Strategy\& analysis Abu Dhabi media, 2014.

Notes: electronic games perception in Egypt 17\% of total population in 2012. Electronic games consumption by platform $71 \%$ of gamers plays electronic games through personal computer, $32 \%$ through smart phones, and $1 \%$ through tablets.

\subsection{Examples of Best Mobile Advergames}

Mobile games are the fastest growing game segment almost doubling its revenue between 2013 and 2015 from $\$ 13$ to $\$ 22$ billion. These advancements of mobile technologies have motivated game designers to create innovative gameplay for diverse purposes and multiple contexts, such as travel and tourismthispoint presents best practices, during and after traveling that pioneered the application of games, to create innovative products and services for the travel and tourism industry(Gaming and Gamification in Tourism, 2014)

\subsection{Location-Based Augmented Reality Games (Creswell, 2014)}

Playing on-site in the tourism destination with a smartphone will be one of the majordevelopments in the next few years. Although already available in some cities such as London, Berlin, Barcelona and Stockholm, advances in mobile technologies enable game experiences out of the tourist's pocket with these little game apps. Location-based games take visitors on individual and interactive walks through the place beingvisited.

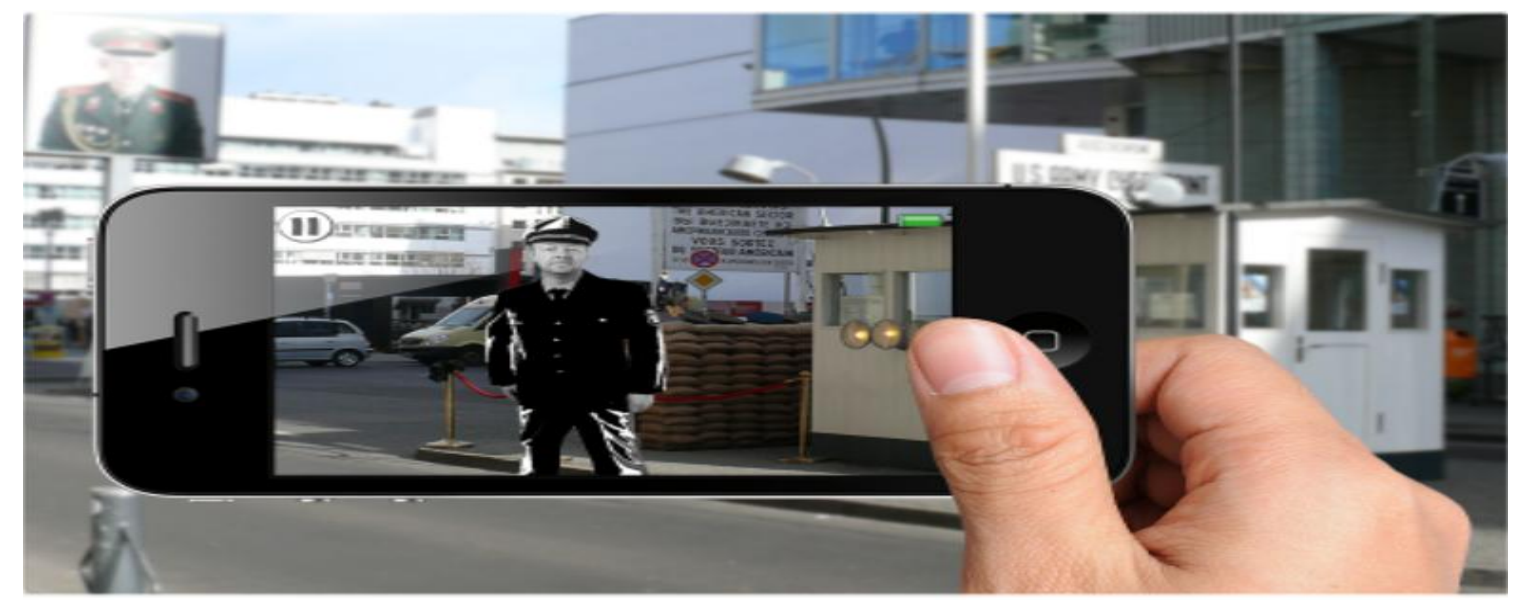

\subsection{Application of Gamification in the Aviation Industry}

Applying game elements in a context other than gaming roots in the travel industry. In the early 1980s, American Airlines introduced it's frequently flyer program to increase brand loyalty. Airlines such as KLM or Virgin America brush up their longstanding loyalty program by integrating social networks.KLM launched the Meet \& Seat feature for passengers to find out who else is on the flight and connect with them via their Facebook, Google+ or LinkedIn profiles. The value for the passengers in sharing their personal details with other customers is to find interesting people or passengers that attend the same event at the destination. 


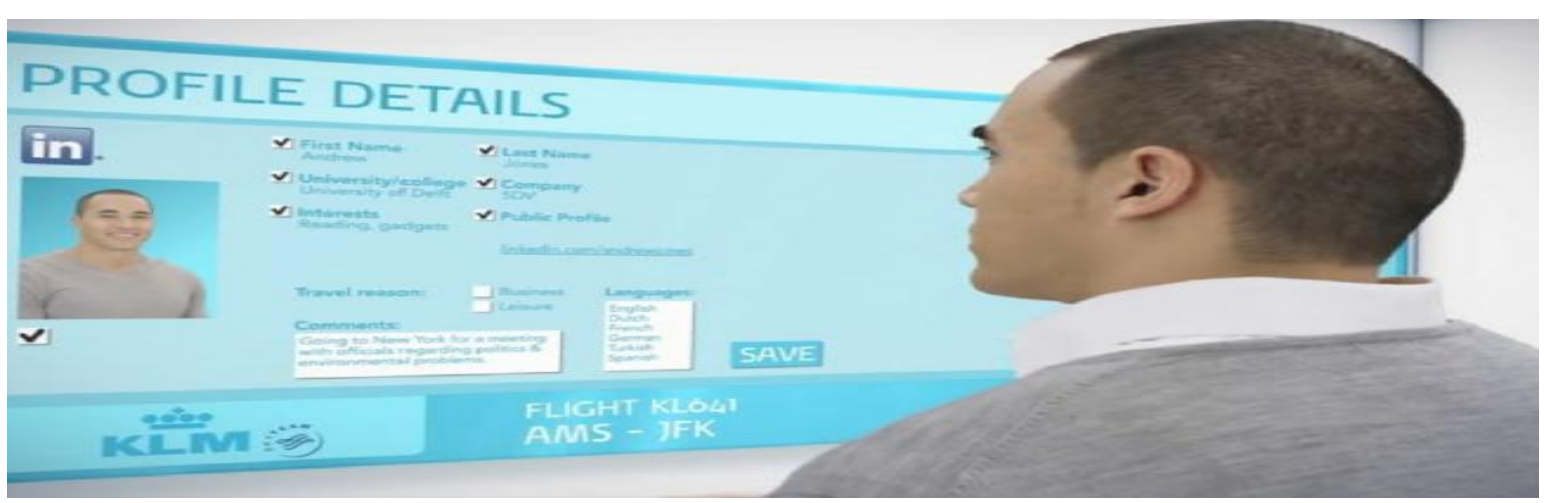

\subsection{Gamified Virtual Travel Experience}

Games for tourism applications are also available for those who want to experience the world from the secure distance of their couch, or are yet indecisive about where to go and would like to try out different travelling styles and destinations in advance.Expedia.com, the world's largest online travel agency, launched a travel Around the World in 100 Days game in June last year. The game was created to increase the awareness of Expedia's loyalty program and engage with customers. Players can earn real-world Expedia Reward points and redeem them on their travel bookings.Derived from the chosen travel persona from the online game, customers receive personalized travel offers and learn more about interesting destinations around theworld(Expedia.com).

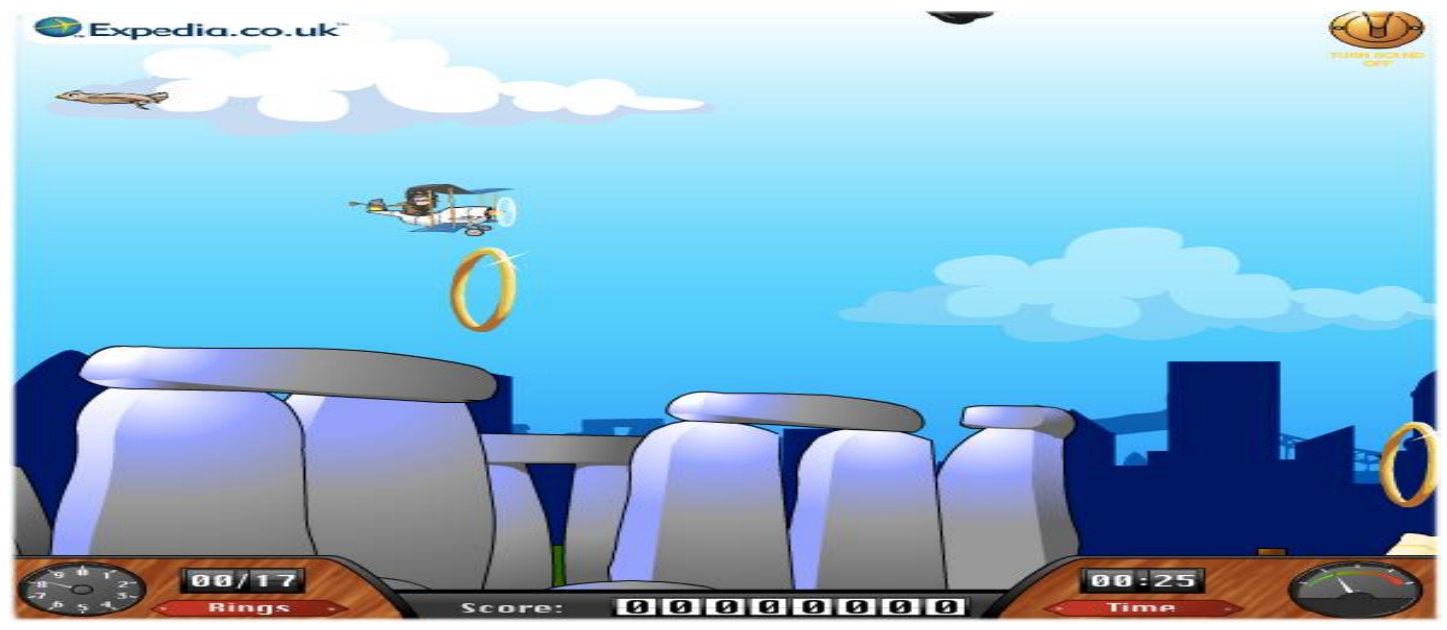

\section{Methodology}

The purpose of this study is to explore the role of creative communication media like Mobile advergames on tourists' attitude andtheir perceptions about destinationsimage. Theprimary hypothesis of this study therefore posits:

H1: There is a stronger positive relationship between creative communication media like Mobil advergames on tourists' perceptions about destinationimage.

This study used both empirical and logical methods for the finding of our intentions. From the group of the empiric methods this study applied quantitative and qualitative research. The method used in this exploratory study adopted a questionnaire to elicit data from a sample of advergame players. And a structured interview to identify the reasons of using Mobile advergames.

The questionnaire oriented to users of Mobil advergames, which aims at characterizing the profiles within a group of users of these kinds of platforms. The questionnaire was constructed using a specialized online tool (http://www.google.com/forms/about/). The use of this tool in research is justified because it allows quick access to the questionnaire and facilitates a faster response. It has also the advantage of analyzing the data obtained. This tool is already used by a considerable number of researchers. For example, Barry et al. (2008) used it in their research and several studies where it was also used. Evans et al. (2009) recommend the use of this service. The types of question fields used in the questionnaire included: multiple choice (one or More answers), and comment box (open response). And check list (Yes or no). 


\section{RESULTS}

33 participation in this questionnaire. The information concerning the gender of the participants is provided in the study. 25.8 percent of theparticipants are female and 24.2 percent are male.

Majority of the participantstheir ages (45.5\%) in the range of $21-30,(18.2 \%)$ in $31-40$ and 41 $50,(6.1 \%)$ more than 50 .

The information concerning the education of the participants is provided in the study 60.6 percent of the participants are university education. The data concerning their own income level of the participants are also indicated in the study 57.6 percent of the participants their income is average and 21.2 percent high income.

The most frequent purposes of using internet by the participants are indicated in the Figure 3.The participants use internet most frequently for the purposes of communicating with the others\&Entertainment (30.3\%), get information (24.2\%), other purposes (15.2\%)

Why you use internet ?

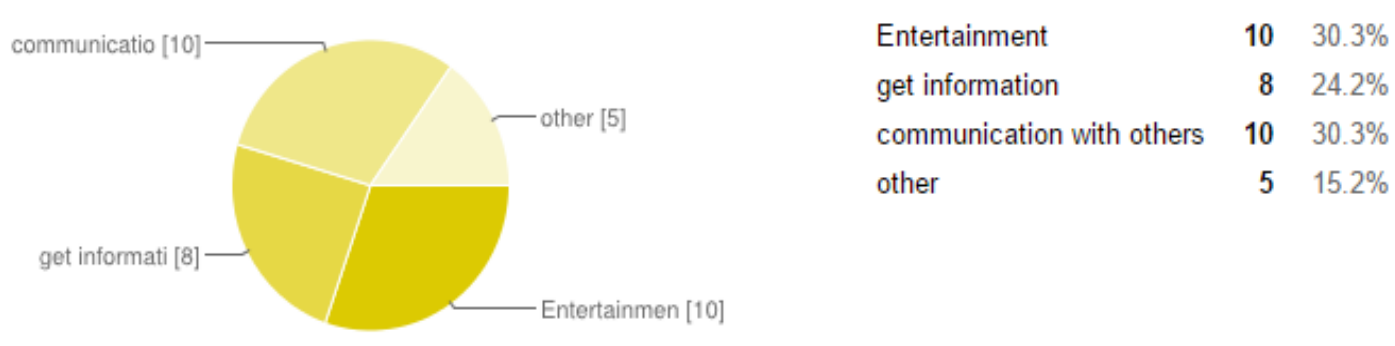

Figure (3)

The data concerning how the participants identify the importance of internet is provided in the Figure (4), $97 \%$ of the participants responded at the important and very important levels for the place of internet in their lives.

\section{The importance of internet for you}

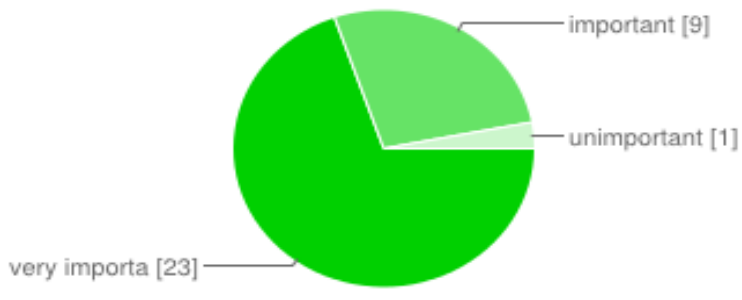

$\begin{array}{lrr}\text { very important } & \mathbf{2 3} & 69.7 \% \\ \text { important } & \mathbf{9} & 27.3 \% \\ \text { unimportant } & \mathbf{1} & 3 \%\end{array}$

Figure (4)

According to the questionnaire, the following results are obtained based on the opinions of theparticipants:

- A large majority of the participants (90.9\%) have information about mobile advergames.

- About (\% 93.9) follow at least one advergame until now.

- About (\%75.8) agreed that When the game and the destination brand were thematically related,brand attracts more attention for you.

- Mobile Advergames mean more destination awareness (\%54.5).

- By Mobile advergaming you can be informed about destination's attractiveness (\%54.5).

- Mobile Advergames can determine my destination choice (\%48.5).

- Game quality led to positive attitude toward destination image (\%81.8).

- You think that Mobile advergames is the future of interactive advertising (\%72.7). 
- According to the Figure (5) Majority of the participants (39.4\%) may be visit Egypt in case pf playing mobile advergames

\section{Will you visit Egypt in case of playing Mobil advergames?}

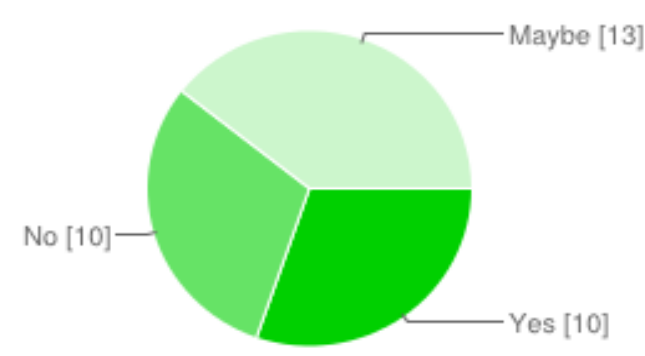

$\begin{array}{lll}\text { Yes } & \mathbf{1 0} & 30.3 \% \\ \text { No } & \mathbf{1 0} & 30.3 \% \\ \text { Maybe } & \mathbf{1 3} & 39.4 \%\end{array}$

Figure (5)

\subsection{Questionnaire Discussion}

This questionnaire has three outcomes which are of relevance to marketing strategists:-

Firstly, the results suggest that players of mobile advergames are receptive to the advertising message or at least to the destination that is displayed within the game.

Secondly, in the research, the participantssaid 'when the game and destination brandwere thematically related, brand attract more attention for me with the proportion of $75,5 \%$. It can besaid that destination brand-related mobile advergames might be more successive as a way of creating positive consumerattitudes towards a particular brand.

Finally, the research has suggested thatmobileadvergames are more effective as a way of developing positive consumerattitudes towards a particular product. According to this, participants think that if the Game quality is good, led to positive attitude toward destination image, Its proportion is $81,8 \%$.

On the other hand, it can be seenthat participants do not magnify the effects of mobile advergames. They think that mobile advergame can determine their brand choice $(48.5 \%)$ andmobile advergames mean more brand awareness (54.5\%). Theanalysis also reveals that participant think mobile advergames are not the source of benefits and attractiveness about destinations. But participantssawmobileadvergamescan be as a future interactive advertising.

These insights may assist marketing strategists in their efforts to determine howmobileadvergames should be positioned in the context of a marketing campaign.

The outcomes of this study need to be considered within the context of its limitations. First, the number of respondents was relatively small $(n=33)$ and with such a small sample it was seemed inappropriate to undertake statistical testing. Any future studies should recruit a larger and more representative sample so that more robust results and conclusions can be drawn.

\subsection{Interviews Discussion}

Five Structured interviews are conducted with web developer, game designer and developerin IT works \& link Solution Company, These interviewshavemany outcomes which are of relevance to marketing strategists:-

First, All interviewees both found that mobile advergames is a great opportunity for integrated marketing efforts. The facility of engaging users has led many destinations to develop games, which has increased not only the interaction level, but has also helped destinations increase their database. They seemobile advergames very suitable for bigger brands, such as tourist destinations because it's usually more expensive. they also see TV ads are expensive and engage the viewer for a limited time but advergames typically engage players for 5 to 35 minutes and gamers often return to play more.These results are consistent with(Shliapnikov, 2014; Cseltek, 2010;Xu, 2012 ; Baggio, 2014). 
Second, Interviwer A (Web develpoer) recognize that company should consider Mobile advergames in their marketing mix "using mobile advergames in your marketing is something significantly different than your competitors do. In order to attract a lot of customers need to be distinctive and innovative Games considered one of very distinctive way ".Has also added "The success of mobile advergame is easily measured, Because prospect data and contact information is gained from game registration, brands can easily track who is visiting the site, the total accumulated hours of game play, and the number of times a game was referred or e-mailed to a friend - all valuable information to marketers " These results are consistent with (Ayada, 2013)

Interviewer B (Game designer) admits that Mobil advergames is an effictive tool in marketing because "Users choose to register to be eligible for prizes, which can help marketers collect customer data. Gamers may also invite their friends to participate, which could assist promotion by word of mouth or 'viral marketing'" These results are consistent with ( $\mathrm{C}_{s}$ eltek, 2010).

Third, All interviewers find that the mobile advergames are expensive the average, well around 20,000 or 55,000. These result is consistent with ( $C_{3}$ eltek, 2010). Most of companiesdid not want design games for their products or brands but put their advertisements during the famous games such as pop-up ads or show advertising message during the game (Banner ads) or advertising appear in gaming sites and gaming pages. Most mobile advergames focus on a specific target group generally, 15-30 boys and girlsthese results are consistent withthe questionnaire and (Perez, 2009).

On the other hand, the researcher sees that interviewers do not magnify the future of mobile advergames. Interviewer C (Web developer) see“marketers believed there was a big opportunity in mobile advergaming. They thought it was a great way of direct communication. They believed that if they'd reach the customers by point of sale, they could quite easy influence the buying behavior. But that wasn't as easy as they thought it would be. The higher cost of building mobile games has for a long time discouraged brands Compared to the means of social communication which are less expensive and the rates of click-through was miniscule and Mobile Advergames still need to be well designed, many mobile advergames focus too much on the advertisement this games lacks of the fun and excitement . The result companies feeling cheated and betrayed" The result of thesemattersthey do not think it will be an important tool in the future.

But other interviewers see Smart phones are growing very quickly. That's mean A huge success in the future because it's considered as a gaming platform.

\section{CONCLUSION}

This paper illustrate that games are a media platform and a very important element from the contemporary culture. Mobile Advergamesare also a great opportunity for integrated marketing efforts. The facility of engagingusers has led many companies to develop games, which has increased not only the interaction level,but has also helped companies increase their database.

Advergaming also increases awareness andrecall. If any consumer gets intrigued by the product, he or she can immediately check the websiteto get more information about the product andmake informed decisions (Lopatina, 2005).

Therefore, Tourism institutions just needsto create a fun mobile advergame about different destinations and attractionsin Egypt, which can drivecustomers to purchase or trial, and establish a long term relationship with them.

\section{BIBLIOGRAPHY}

[1] Adrián Domínguez, J. S.-d.-N.-M.-S. (2013). Gamifying learning experiences: Practical implications and outcomes. Computers \& Education.

[2] Ayada, W. M. (2012). Advergames on Facebook a new approach to improve the Fashion. International Design Journal.

[3] Ayada, W. M. (2013). Advergames on Facebook a new approach to improve the Fashion. International Design Journal.

[4] Baggio, R. (2014). Information and Communication Technologies in Tourism. 
[5] Buckner, T. W. (2010). RECEPTIVENESS OF GAMERS TO EMBEDDED BRAND MESSAGES IN. Journal of Interactive Advertising.

[6] Bughin, J. (July 2011). The impact of Internet technologies.

[7] Cs eltek, E. (2010). Mobile advergames intourism marketing. Journal of Vacation Marketing.

[8] Çeltek, E. (n.d.). Mobile advergames in tourism marketing. 2010.

[9] Creswell, J. W. (2014). Research Design: Qualitative, Quantitative and Mixed Methods Approaches (4 ed.). London: Sage Publications Ltd.

[10] D.Pop, M. (2013). CONSUMER ATTITUDES TOWARDS ADVERTISING IN.

[11] Eric Klopfer, S. O. (2012). moving learning games forward.

[12] G. De Prato, C. F. (2010). ASSESSING THE FUTURE COMPETITIVENESS OF THE EU VIDEO GAMES SOFTWARE INDUSTRY.

[13] Gaming and Gamification in Tourism. (2014). Retrieved from Gamification in Tourism Best Practice Report.

[14] GHIRVU, A. I. (2013). THE AIDA MODEL FOR ADVERGAMES.

[15] Graaf, S. v. (2007). Information Communication Technologies and Emerging Business Strategies.

[16] Groot, R. d. (2012). IT-BASED RISKS IN ADVERGAME CAMPAIGNS.

[17] GURA`U, C. L. (2008). The Influence of Advergames on Players. In C. L. GURA־U, INTERNET MARKETING.

[18] Kretchmer, S. B. (2003). The Emergent Advergames Industry: Developments, Impact, and Direction.

[19] Lizzy Bleumers, A. A. (2012). State of Play of Digital Games for Empowerment and Inclusion.

[20] Marius, D. (2013). CONSUMER ATTITUDES TOWARDS ADVERTISING IN.

[21] Mráček Pavel, M. M. (2013). Application of Knowledge in Advergaming.

[22] Mucha, M. (2013). Advergaming: Application of Knowledge in the Process of the Competitive.

[23] Pavel Mráek, M. M. (2012). Advergaming: Application of Knowledge in the Process of the Competitive. Trends economics and management.

[24] Perez, A. C. (2009). Exploring the possibilities of Videogames as an advertising platform.

[25] Przybylski. (2010). A motivational model of video game engagement. Review of General Psychology.

[26] Rigby, R. (2006). The motivational pull of video games: a self-determination theory approach. Motivation and Emotion.

[27] Shliapnikov, T. M. (2014). The use of advergames in creating online.

[28] Staalduinen, J.-P. V. (2012). Gamers on Games and Gaming.

[29] Theodorou, L. (2010). Advergames' Content Analysis: Applying a Methodological Toolkit based on Ludology Principles.

[30] Tina Winkler, K. B. (2006). Receptiveness of Gamers to Embedded Brand Messages in Advergames. UK.

[31] Tuten, T. L. (2008). SOCIAL MEDIA MARKETING IN AWEB 2.0 WORLD.

[32] Wynn-Brown, S. (2007). Product and Promotion: Creating and Communicating Value. In S. Wynn-Brown.

[33] Xu, F. (2012). Marketing tourism via electronic games.

[34] Advergaming today. (2006). Retrieved from http://advergamingtoday.org/2006/03/types-ofadvergames.html

[35] Advergame. (2013). Retrieved from 7 reasons you need an advergame: http://www.rockpocketgames.org/ abou t-advergames/

[36] Advergaming. (2007). Retrieved from http://morgantrent.blogspot.eg/2007_12_01_archive.html

[37] Advergaming. (2014). Retrieved from http://www.zgroup-mobile.org/advergaming.html

[38] Advertising in video games. (2008). Retrieved from http://en.wikipedia.org/wiki/Advertising_in_video_ games

[39] Booth, S. (2014). Technology Drives Travel Spontaneity in Egypt, Saudi Arabia and the UAE. Retrieved from http://research.mena.yougov.org/en/news/2014/09/24/technology-drives-travel-spontaneity-egyptsaudi-a/

[40] Baron-Cohen, S. (2010). HOW IS THE INTERNET CHANGING THE WAY YOU THINK? Retrieved from https://edge.org/responses/how-is-the-internet-changing-the-way-you-think

[41] Justin. (2008). Branded Mobile Adver Gaming on the Rise? Retrieved from http://www.mobilemar ketingwatch.org /branded-mobile-advergaming-on-the-rise-943/ 
Investigating the Effectiveness of Applying Mobile Advergames in Tourism Marketing - An Exploratory Study about Egypt

[42] Okur, G. (2011). advergamingg. Retrieved from https://advergamingg.wordpress.com/advergaming2/types-of-advergaming/

[43] Picurelli, L. (2013). Advergaming: the most addictive mobile marketing strategy. Retrieved from http://en.Yee ply.eg/blog/advergaming-the-most-addictive-mobile-marketing-strategy/

Citation: Mrs/ Yasmine Elsayeh. "Investigating the Effectiveness of Applying Mobile Advergames in Tourism Marketing - An Exploratory Study about Egypt". International Journal of Research in Tourism and Hospitality (IJRTH), vol 6, no. 2, 2020, pp. 21-32. doi: http://dx.doi.org/10.20431/2455-0043.0602003.

Copyright: () 2020 Authors. This is an open-access article distributed under the terms of the Creative Commons Attribution License, which permits unrestricted use, distribution, and reproduction in any medium, provided the original author and source are credited. 